\title{
ON THE INTRODUCTION OF E-LEARNING PORTFOLIO IN THE EDUCATIONAL PROCESS
}

\section{Nargiza Rasuljanovna Ismatullayeva}

Phd In Philological Sciences, Lecturer, Department Of Translation Studies And International Journalism, Tashkent State University Of Oriental Studies, Tashkent, Uzbekistan

\section{ABSTRACT}

This article discusses the essence and content, structural components, advantages of the electronic learning portfolio, which are considered effective pedagogical methods in modern education. The article also shows the results of the introduction of electronic portfolio in the educational process.

KEYWORDS:- Learning portfolio, e-learning, exchange of information between teacher and student, teacherstudent collaboration.

\section{INTRODUCTION}

The priority task of the President is to raise the state youth policy to a higher level in line with modern requirements. In this regard, Sh.M.Mirziyoev notes the following: "We will mobilize all the forces and capabilities of our state and society for the development and happiness of our young people as independent thinkers, with high intellectual and spiritual potential, who will not be idle to their peers in any field around the world" [1].

The importance of the educational portfolio in the development of education, its content and structure can be illustrated by the research work of scholars such as J. Zubizarreta [2], [3], D.Skalli, M.OLeari and M.Braun [4], D.Kempbel, B.Melenizer, D. Nettles and R. Wiman [5].

\section{THE MAIN FINDINGS AND RESULTS}

The study portfolio is now well known and widely involved in scientific fields as well. Usually portfolios are in the form of documents attached to each other. These documents allow students and teachers to demonstrate and evaluate their knowledge, skills and abilities. Some portfolios are shared by students and faculty advisors with others for academic counseling and career guidance. The National Council for Accreditation of Teacher Education (NCATE) recommends the portfolio model as an effective tool for demonstrating the knowledge, skills, and competencies acquired for professional achievement and career preparation $[2,1]$.

According to D. Sculli and co-authors, the educational portfolio is a concept that helps to 
CURRENT RESEARCH JOURNAL OF PEDAGOGICS 2(9): 35-37, September

2021 DOI: https://doi.org/10.37547/pedagogics-crjp-02-09-08

ISSN 2767-3278

(C)2021 Master Journals

\section{Crossref dof 80 Google}

Accepted 15th September, 2021 \& Published 20 ${ }^{\text {th }}$ September, 2021

regulate their actions in the learning process, to carry out cognitive monitoring and to develop the spirit of lifelong learning $[4,3]$.

The student portfolio comes in a variety of forms depending on the purpose and individual or program design. The following is a simple model of a training portfolio consisting of three main components:

1) Feedback

2) Documents

3) Collaborate.

The combination of any two components guarantees a deeper learning experience. However, if students activate all three components in a portfolio project, the chances of improving the quality of reading increase even more $[3,3]$.

J. Zubizarreta describes the content of the components of the training portfolio as follows:

1. Philosophy of education (What, how, when and why did I learn?)

2. Achievements in the learning process (What did I achieve as a result of studying?)

3. Learning Evidence (What products, developments do I have to demonstrate my knowledge?)

4. Assessment of learning (What are the criteria for assessing my knowledge?)

5. The importance of education (How has reading changed my life?)

6. Learning Objectives (What plans do I have to continue my studies?) [2, 4]

If the project of the training portfolio is prepared on the basis of the content of these specified components, the portfolio will achieve the set purpose.

In the current process of globalization, our students have also changed completely. Modern students have a very different worldview than before, the ability to accept knowledge, a unique reaction to events, and these factors require changes in the traditional education system.

Well-known American scientist Mark Prensky uses the term "Digital natives" in reference to today's youth, noting that this generation today is a young people who are fluent in computers, video games and the digital language of the Internet. According to him, the "cyber generation" is a young generation accustomed to finding and retrieving information quickly, likes the use of graphics, short information, web pages, prefers to "work" in a game style than "serious" work [6, 1-3].

In this sense, the introduction of an educational portfolio in electronic form is fully consistent with the needs and capabilities of the so-called "cyber generation". In order to put into practice the knowledge gained as a result of the abovementioned online courses "School of Skills", a group of students of the Department of Translation Theory and Practice of the Tashkent State Institute of Oriental Studies was tasked to create an e-learning portfolio. The Google sites platform was chosen to create such portfolios because of their ease of learning and use. The following documents, which are part of the traditional educational portfolio, have been included in the student's educational portfolio in electronic form:

- Student's reference (resume);

- Developments such as presentations, abstracts, essays for the best independent study of disciplines in the process of studying at the institute;

- Scientific articles written by the student;

- Translations performed by the student;

- Various certificates, certificates of honor, letters of appreciation; 
CURRENT RESEARCH JOURNAL OF PEDAGOGICS 2(9): 35-37, September

2021 DOI: https://doi.org/10.37547/pedagogics-crjp-02-09-08

ISSN 2767-3278

(C)2021 Master Journals

\section{Crossref do) 11 Google}

Accepted 15th September, 2021 \& Published 20 ${ }^{\text {th }}$ September, 2021

- Photo gallery related to the learning process.

As a result of this small experiment, it is important to show that students are motivated in the first place. In order to replenish their elearning portfolios and present them to the general public, students have to make quality and more developments, make artistic written translations, strive for certificates and honorary diplomas.

\section{Conclusion}

In conclusion, a number of the advantages of such a systematically prepared e-learning portfolio can be summarized as follows. First, Curtis J. Bank notes that in the XXI century, the opportunities for exchange of views, information, cooperation in the field of education are growing. In particular, the ability of the scientist to exchange information leads to the emergence of various online collaboration technologies between teacher and student $[7,91]$, through the creation of a learning portfolio opens the way for information exchange between student and teacher, cooperation is established. Second, unlike the traditional training portfolio, the electronic version leads to significant savings (saving paper, time, space, etc.). Third, the student will have the opportunity to enrich their e-portfolio as regularly as they wish. Fourth, the activities in the educational, scientific, creative, spiritual and educational spheres in the process of studying at the university are monitored by people interested in the activities of the student, allowing employers to obtain detailed information about the student.

\begin{abstract}
state of Uzbekistan. - Tashkent. "Uzbekistan". (Мирзиёев Ш.М. Эркин ва фаровон, демократик Ўзбекистон давлатини биргаликда барпо этамиз. Тошкент: “Ўзбекситон”, 2016.)
\end{abstract}

2. Zubizarreta J. The learning portfolio: A powerful idea for significant learning. Columbia College, 2008.

3. Zubizarreta J. The learning portfolio: Reflective practice for improving student learning. Bolton, MA: Anker, 2004.

4. Scully D., O'Leary M., Brown M. The Learning portfolio in Higher Education: A game of snakes and ladders. Dublin, 2018.

5. Campbell D.M., Melenyze B.J, Nettles D.H. \& Wyman R.M. Portfolio and performance assessment in teacher education. Boston, MA: Allyn and Bacon, 2000.

6. Prensky M. Digital natives, digital immigrants. From On the Horizon. MCB University Press, Vol. 9 No. 5, 2001.

7. Curtis J. Bonk. The World is open: How web technology is revolutionizing education. Available: https://www.slideshare.net/druelyn/theworld-is-open-curtis-jbonk 2011.

\section{REFERENCES}

1. Mirziyoev Sh.M. (2016) Together we will build a free and prosperous, democratic 